\title{
PENINGKATAN HASIL BELAJAR SISWA MELALUI MODEL PEMBELAJARAN INTERAKTIF MELALUI PENGOPERASIAN PROGRAM MICROSOFT POWERPOINT PADA MATA PELAJARAN TEKNOLOGI PERKANTORAN DI SMK NEGERI 7 MEDAN
}

\author{
Darmauli ${ }^{1 *}$ \\ 1) SMK Negeri 7 Medan \\ *Penulis korespondensi: darmauli.pjt@gmail.com
}

\begin{abstract}
Tujuan penelitian ini adalah untuk meningkatkan hasil belajar siswa pada Kompetensi DasarMengoperasikan Program Microsoft Powerpointdalam mata pelajaran Teknologi Perkantoran melalui penggunaan model pembelajaran interaktif di kelas X Otomatisasi dan Tata Kelola Perkantoran 2 SMK Negeri 7 Medan. Jenis penelitian yang dilakukan dalam penelitian ini adalah Penelitian Tindakan Kelas (PTK). Penelitian dilakukan pada siswa kelas X Otomatisasi dan Tata Kelola Perkantoran 2 SMK Negeri 7 Medan T.P2018/2019. Penelitian ini menggunakan tiga siklus dan analisis deskripsi kualitatif. Hasil penelitian ini menunjukkan bahwa hasil belajar siswa pada pretes masih rendah. Setelah dilakukan proses pembelajaran dengan menggunakan model pembelajaran interaktif hasil belajar siswa sudah mulai meningkat walaupun belum mencapai tingkat ketuntasan belajar. Kemudian dilakukan perbaikan pada siklus II hasil belajar siswa terjadi peningkatan yaitu dengan tingkat ketuntasan belajar $94 \%$ dan yang tidak tuntas belajar hanya $6 \%$ siswa.
\end{abstract}

Keywords: Hasil belajar, Pembelajaran interaktif, Microsoft Powerpoint, Teknologi Perkantoran, Penelitian tindakan kelas, SMKN 7 Medan

Article Information:

Received Date: 7 Januari 2022

Revised Date: 13 Januari 2022

Accepted Date: 2 Maret 2022 


\section{PENDAHULUAN}

Pendidikan merupakan hal yang sangat penting untuk mewujudkan masyarakat yang berkualitas dan bertanggung jawab untuk mempersiapkan diri menuju hidup yang lebih baik. Meningkatnya mutu pendidikan adalah tanggungjawab semua pihakyang terlibat dalam pendidikan. Adapun aspek-aspek tersebut diantaranya : kurikulum, kepala sekolah, guru, siswa, masyarakat, sarana dan prasarana, media, metode, strategi, pendekatan dan lain sebagainya. Salah satu faktor yang mendukung berhasilnya pendidikan yaitu guru. Guru merupakan ujung tombakdalam pendidikan terutama guru. Oleh sebab itu guru sangat berperan dalam menciptakansumber daya manusia yang berkualitas yang dapat bersaing di zaman pesatnyaperkembangan teknologi. Guru dalam setiap pembelajaran harus menggunakanpendekatan, strategi dan metode pembelajaran yang dapat memudahkan siswa memahamimateri yang diajarkannya, namun masih sering terdengar keluhan dari para guru dilapangan tentang materi pelajaran yang terlalu banyak dan keluhan kekurangan waktuuntuk mengajarkannya.

Mata pelajaran Teknologi Perkantoran atau Pengotomatisan Perkantoran secara umum, bertujuan untuk sebuah upaya yang dilakukan dengan memanfaatkan perkembangan teknologi yang ada dan menerapkannya kedalam perkantoran dengan tujuan dapat memudahkan proses pekerjaan menjadi lebih efisien dan efektif sehingga dapat lebih mengembangkan perusahaan. (Kurikulum Tingkat Satuan Pendidikan, 2013).

Pengembangan Kurikulum Tingkat Satuan Pendidikan mengacu pada standar nasional pendidikan untuk menjamin pencapaian tujuan pendidikan nasional. Tujuan pengembangan Kurikulum Tingkat Satuan Pendidikan adalah untuk memberikan acuan kepada kepala sekolah, guru, dan tenaga pendidik lainnya yang ada di sekolah dalam mengembangkan program-program yang akan dilaksanakan.

Hal ini hanya dapat tercapai apabilaproses pembelajaran yang berlangsung mampu mengembangkan seluruh potensi yang dimiliki siswa, dan siswa terlibat langsung dalam pembelajaran. Untuk itu guru perlu meningkatkan mutu pembelajarannya, dimulai dengan rancangan pembelajaran yang baik dengan memperhatikan tujuan, karakteristik siswa, materi yang diajarkan, dan sumber belajar yang tersedia. Kenyataannya masih banyak ditemui proses pembelajaran yang kurang berkualitas, tidak efisien dan kurang mempunyai daya tarik, bahkan cenderung membosankan, sehingga kompetensi yang dicapai tidak optimal. Hal ini dapat dilihat dari hasil belajar siswa pada pelajaran Teknologi Perkantoran di kelas X Otomatisasi dan Tata Kelola Perkantoran 2 SMK Negeri 7 Medanyaitu dengan nilai rata-rata 57,63. Nilai tersebut masih berada dibawah KKM yakni 70,00 .

Hal tersebut disebabkan karena pada umumnya dalam proses pembelajaran guru tidak menggunakan media, padahal media merupakan sesuatu yang mutlak dalam pembelajaran. Dengan menggunakan media siswa akan memahami konsep yang akan disampaikan dengan mudah dan dengan media siswa tidak memiliki persepsi sendiri mengenai suatu konsep yang disampaikan.Tidak tersedianya media serta kurangnya pengalaman dan informasi yang diperoleh guru juga merupakan faktor yang menyebabkan guru tidak menggunakan media dalam proses belajar mengajar. Guru tidak terlatih untuk menggunakan media dari berbagai alat yang telah menggunakan teknologi seperti komputer dan lain sebagainya

Sarana dan prasarana juga merupakan bagian terpenting dalam proses pembelajaran. Letak sekolah yang jauh dari perkotaan juga menghambat kreatifitas guru dalam mengembangkan media pembelajaran. Tempat praktek perkantoran yang disesuaikan dengan Dunia industri atau dunia Usaha (DU/DI) yang berada di sekolah sangat membantu guru'

Guru menemukan bahwa dalam proses pembelajaran guru menyampaikan pelajaran hanya dengan menggunakan metode 
konvensional atau ceramah saja, dimana guru lebih aktif sebagai pemberi pengetahuan bagi siswa sedangkan siswa pasif hanya menerima masukan saja.

Hal ini disebabkan kurangnya penguasaan guru terhadap metode dan model pembelajaran yang ada. Banyak model-model pembelajaran yang ada tetapi tidak semua dari model pembelajaran tersebut dapat digunakan untuk mengajarkan semua kompetensi dasar dalam pembelajaran.

Model pembelajaran interaktif merupakan model pembelajaran yang sangat cocok untuk diterapkan dalam menyampaikan materi Pengoperasian Program Microsoft Power Point Pada Mata Pelajaran Teknologi Perkantoran pada siswa kelas X Otomatisasi dan Tata Kelola Perkantoran 2 SMK Negeri 7. Medan, karena Model pembelajaran interaktif mengajak siswa untuk aktif baik dalam bertanya, mengajukan pertanyaan dan berdiskusi dan mempraktekkan dalam pembuatan materi-materi presentasi yang menarik dan berkualitas dalam penyampian hasil diskusi atau kerja kelompok. Apabila model ini diterapkan oleh guru-guru maka guru tersebut tidak akan memperoleh siswanya dalam keadaan mengantuk atau menghayal karena mendengarkan ceramah dari guru.

\section{TINJAUAN PUSTAKA}

\section{Hakikat Hasil Belajar}

Belajar merupakan salah satu bentuk prilaku yang amat penting bagi kelangsungan hidup manusia. Belajar membantu manusia menyesuaikan diri (adaptasi) dengan lingkungannya. Dengan adanya proses belajar inilah manusia bertahan hidup (survived). Belajar secara sederhana dikatakan sebagai proses perubahan dari belum mampu menjadi sudah mampu, terjadi dalam jangka waktu tertentu. Menurut Gredle dalam Syafaruddin (2005:59) bahwa "belajar merupakan faktor yang luas dibentuk oleh pertumbuhan, perkembangan tingkah laku".

Dari pendapat diatas, belajar adalah suatu proses perubahan yang dipengaruhi faktor yang luas yang dapat dilihat dari perubahan tingkah laku yang dibetuk oleh pertumbuhan. perubahan tingkahlaku tersebut terjadi dalam jangka waktu tertentu.

Menurut Sukmadinata (2005:5) "hasil belajar atau achievement merupakan realisasi atau pemekaran dari kecakapan-kecakapan potensial atau kapasitas yang dimiliki seseorang". Penguasaan hasil belajar oleh seseorang dilihat dari prilakunya, baik prilaku dalam bentuk penguasaan pengetahuan, ketrampilan berpikir maupun ketrampilan motorik.

Ringin Gung Murti Sutomo juga membuktikan bahwa penggunaan media pembelajaran interaktif dengan bahan cetak ajar overhaul sisten pendingin dapat meningkatkan hasil belajar siswa dibandingkan tanpa menggunakan media pembelajaran interaktif.

Sukamto, penerapan pembelajaran menggunakan Model Pembelajaran Interaktif dapat meningkatkan prestasi belajar dan pemahaman konsep tentang materi Kenampakan Alam dan Social Negara-Negara Tetangga IPS dalam Materi Kenampakan Alam dan Sosial Negara-Negara Tetangga

Dari pendapat diatas, hasil belajar merupakan kenyataan dari kecakapan potensial dan kemampuan yang dimiliki seseorang. Pemahaman hasil belajar seseorang dapat dilihat dari perubahan baik dari aspek pengetahuan, keterampilan berfikir maupun keterampilan motorik.

\section{Faktor-Faktor Yang Mempengaruhi Hasil Belajar}

Hasil belajar merupakan gambaran dari tingkat penguasaan subjek belajar terhadap sesuatu yang diperoleh dari suatu proses belajar. Harus diingat bahwa setiap pembelajar tidak mempunyai hasil belajar yang sama, meskipun diajar diruang yang sama dan dan diberikan materi yang sama serta sarana yang sama. Menurut Slameto (2003:54) faktorfaktor yang mempengaruhi hasil belajar seseorang adalah sebagai berikut : 
1. Faktor Internal, terdiri dari : a. Faktor biologis (jasmaniah) meliputi segala hal yang berhubungan dengan keadaan fisik atau jasmani individu yang bersangkutan. b. Faktor Psikologisyang mempengaruhi keberhasilan belajar siswa meliputi intelegensi siswa / tingkat kecerdasan, perhatian, minat, bakat, motif/dorongan, kematangan dan kesiapan siswa.

2. Faktor Eksternal merupakan faktor yang bersumber dari luar individu itu sendiri. Faktor eksternal meliputi faktor lingkungan keluarga, lingkungan sekolah, dan lingkungan masyarakat.

\section{Hakikat Model Pembelajaran Interaktif}

Pemilihan model yang tepat merupakan hal yang paling penting untuk meningkatkan hasil belajar siswa. Metode yang monoton membuat siswa bosan dan tidak terpacu untuk berprestasi. Model pembelajaran interaktif merupakan salah satu model pembelajaran yang paling tepat digunakan dalam pembelajaran dikelas IX SMK Negeri 7. Medan karena model pembelajaran interaktif merupakan gabungan dari beberapa metode yang dapat membuat siswa katif didalam kelas selama proses belajar mengajar berlangsung.

Menurut Joyce \& Weil dalam Rusman (2010:133) "model pembelajaran adalah suatu rencana atau pola yang dapat digunakan untuk membentuk kurikulum (rencana pembelajaran jangka panjang), merancang bahan-bahan pembelajaran dan membimbing pembelajaran di kelas". Sedangkan menurut Syafaruddin (2005:182) "model pembelajaran adalah bantuan alat-alat yang mempermudah siswa dalam belajar". Menurut Suyatno (2009:78) mengemukakan bahwa "model adalah sesuatu yang dirancang untuk membantu stuktur siswa atau membentuk skemata bagi hubungan antar siswa".

Menurut Harlen (1992:40) mengatakan bahwa "model pembelajaran interaktif sering dikenal dengan nama pendekatan pertanyaan anak, model ini dirancang agar siswa akan bertanya dan kemudian menemukan jawabanpertanyaan mereka sendiri".

\section{Langkah-Langkah Pembelajaran Interaktif}

Model pembelajaran interaktif sering dikenal dengan nama pendekatan pertanyaan anak. Model ini dirancang agar siswa akan bertanya dan kemudian menemukan jawaban pertanyaan mereka sendiri. Meskipun anakanak mengajukan pertanyaan dalam kegiatan bebas, pertanyaan-pertanyaan tersebut akan terlalu melebar dan seringkali kabur sehingga kurang terfokus. Tanya jawab memungkinkan guru untuk memeriksa pemahaman murid tentang pelajaran.

$$
\text { Menurut Harlen }
$$

pendekatan pembelajaran interaktif memiliki langkah-langkah sebagai berikut :

1. Persiapan, sebelum pembelajaran dimulai guru menugaskan siswa untuk membawa beberapa jenis magnet.

2. Kegiatan penjelajahan, pada saat pembelajaran di kelas siswa lain boleh mengamati benda yang dibawa temantemannya dari dekat dan mereka boleh mengajukan pertanyaan.

3. Pertanyaan siswa diarahkan guru sekitar listrik statis.

4. Penyelidikan, guru dan siswa memilih pertanyaan untuk dieksplorasi lebih jauh. Tentu saja pertanyaan yang berhubungan dengan materi yang disajikan.

5. Refleksi, pada pertemuan berikutnya di kelas dibahas hasil penyelidikan mereka.

Salah satu kebaikan dari model pembelajaran interaktif adalah bahwa peserta didik belajar mengajukan pertanyaan, mencoba merumuskan pertanyaan, dan mencoba menemukan jawaban terhadap pertanyaan sendiri dengan melakukan diskusi kelompok.

Pembelajaran interaktif merinci langkahlangkah dan menampilkan suatu struktur pembelajaran yang melibatkan pengumpulan dan pertimbangan terhadap pertanyaanpertanyaan peserta didik sebagai pusatnya. Keberanian siswa untuk mengajukan pertanyaan yang diajukan terhadap obyek yang diamati merupakan langkah awal untuk belajar terampil dalam berpikir. 
Sesuai dengan karakterisik pendekatan interaktif, maka pertanyaan-pertanyaan siswa perlu digali. Pertanyaan-pertanyaan yang muncul mencerminkan rasa ingin tahu siswa setelah melakukan kegiatan eksplorasi. Kegiatan bertanya dapat membantu siswa untuk memperoleh umpan balik. Dengan siswa mengajukan pertanyaan guru dapat mengetahui pengetahuan awal siswa dengan pertanyaan yang diajukannya.

Kelebihan model pembelajaran interaktif adalah guru mengajak siswa untuk aktif baik dalam bertanya, mengajukan pertanyaan dan berdiskusi. Apabila model ini diterapkan oleh guru-guru maka guru tersebut tidak akan memperoleh siswanya dalam keadaan mengantuk atau menghayal karena mendengarkan ceramah dari guru.

Model pembelajaran interaktif juga memiliki kelemahan bagi siswa yang pasif atau pemalu. Siswa yang pasif tidak berani bertanya atau menjawab pertanyaan baik dari guru maupun dari teman sekelasnya. Akibatnya siswa yang pasif hanya akan diam selama proses pembelajaran. Namun didalam satu kelas siswa yang pasif tidak banyak, kebanyakan siswa sangat aktif apabila diberikan kesempatan untuk melakukan penjelajahan dalam pembelajaran.

\section{METODE PENELITIAN}

Jenis penelitian yang dilakukan dalam penelitian ini adalah Penelitian Tindakan Kelas (PTK) atau dengan nama lain Classroom Action Research yaitu suatu model penelitian yang dikembangkan di kelas sesuai dengan kebutuhan atau permasalahan yang terjadi didalam kelas tersebut. Sesuai dengan jenis penelitian ini, maka penelitian ini memiliki tahap-tahap penelitian berupa siklus.

Penelitian dilakukan pada siswa kelas X Otomatisasi dan Tata Kelola Perkantoran 2 SMK Negeri 7 Medan T.P2018/2019. Subjek penelitian tindakan kelas ini adalah siswa kelas X Otomatisasi dan Tata Kelola Perkantoran 2SMK Negeri 7 Medan T.P2018/2019 yang berjumlah 36 siswa. Sedangkan objek yang digunakan pada penelitian ini adalah model pembelajaran interaktif.

Hasil belajar yang dimaksud dalam penelitian ini adalah nilai yang telah diperoleh siswa setelah mengikuti proses pembelajaran melalui penggunaan model pembelajaran interaktif dalam mengoperasikan Program Microsoft Powerpoint yang diperoleh dengan menggunakan tes hasil belajar. Model pembelajaran interaktif yang dimaksud dalam penelitian ini adalah suatu cara penyajian bahan ajar yang dilakukan oleh guru pada proses belajar mengajar dengan melibatkan pikiran, penglihatan, pendengaran, dan psikomotor yang dimiliki siswa. Sehingga memberikan kesempatan kepada siswa untuk mengadakan tanya jawab kepada siswa lain maupun guru. Apabila ada pertanyaan yang tidak dapat diselesaikan oleh siswa maupun guru maka dapat diselesaikan dengan cara mendiskusikannya bersama-sama di dalam kelas.

\section{HASIL DAN PEMBAHASAN}

Penelitian tindakan kelas dilakukan dalam 2 siklus. Siklus I 2 x pertemuan dan siklus II $2 \times$ pertemuan. Siswa yang terlibat dalam penelitian ini berjumlah 36 orang. Selama penelitian berlangsung, kehadiran siswa diupayakan $100 \%$ agar tidak mempengaruhi kesimpulan hasil penelitian. Sebelum diberikan pembelajaran, terlebih dahulu siswa diberikan pretes dengan tujuan untuk mengetahui kemampuan awal siswa pada materi yang akan diajarkan.

Dari hasil pretes yang dilakukan, diperoleh nilai siswa sebagai berikut :

Tabel 1 Daftar Nilai Siswa Pada Pretes

\begin{tabular}{|c|c|c|c|}
\hline No. & Nomor Siswa & Nilai & Keterangan \\
\hline 1 & 01 & 35 & Belum Tuntas \\
\hline 2 & 02 & 70 & Tuntas \\
\hline 3 & 03 & 20 & Belum Tuntas \\
\hline 4 & 04 & 25 & Belum Tuntas \\
\hline 5 & 05 & 40 & Belum Tuntas \\
\hline 6 & 06 & 40 & Belum Tuntas \\
\hline 7 & 07 & 20 & Belum Tuntas \\
\hline 8 & 08 & 35 & Belum Tuntas \\
\hline 9 & 09 & 40 & Belum Tuntas \\
\hline 10 & 10 & 40 & Belum Tuntas \\
\hline 11 & 11 & 30 & Belum Tuntas \\
\hline
\end{tabular}




\begin{tabular}{|c|c|c|c|}
\hline 12 & 12 & 25 & Belum Tuntas \\
\hline 13 & 13 & 35 & Belum Tuntas \\
\hline 14 & 14 & 45 & Belum Tuntas \\
\hline 15 & 15 & 35 & Belum Tuntas \\
\hline 16 & 16 & 65 & Belum Tuntas \\
\hline 17 & 17 & 25 & Belum Tuntas \\
\hline 18 & 18 & 40 & Belum Tuntas \\
\hline 19 & 19 & 65 & Belum Tuntas \\
\hline 20 & 20 & 35 & Belum Tuntas \\
\hline 21 & 21 & 35 & Belum Tuntas \\
\hline 22 & 22 & 70 & Tuntas \\
\hline 23 & 23 & 20 & Belum Tuntas \\
\hline 24 & 24 & 25 & Belum Tuntas \\
\hline 25 & 25 & 40 & Belum Tuntas \\
\hline 26 & 26 & 40 & Belum Tuntas \\
\hline 27 & 27 & 20 & Belum Tuntas \\
\hline 28 & 28 & 35 & Belum Tuntas \\
\hline 29 & 29 & 40 & Belum Tuntas \\
\hline 30 & 30 & 40 & Belum Tuntas \\
\hline 31 & 31 & 30 & Belum Tuntas \\
\hline 32 & 32 & 25 & Belum Tuntas \\
\hline 33 & 33 & 35 & Belum Tuntas \\
\hline 34 & 34 & 45 & Belum Tuntas \\
\hline 35 & 35 & 35 & Belum Tuntas \\
\hline 36 & 36 & 65 & Belum Tuntas \\
\hline \multicolumn{2}{|c|}{ Jumlah Nilai } & 1377 & \\
\hline \multicolumn{2}{|c|}{ Rata-rata Nilai } & 38,25 & \\
\hline
\end{tabular}

Tabel 2 Data Hasil Pretes Siswa Kelas X Otomatisasi dan Tata Kelola Perkantoran 2 SMK Negeri 7 Medan

\begin{tabular}{|c|c|c|c|c|}
\hline No & Nilai & Jumlah & Persentase & Keterangan \\
\hline 1 & $70-100$ & 2 & $6 \%$ & Tuntas \\
\hline 2 & $0-69$ & 34 & $94 \%$ & $\begin{array}{l}\text { Belum } \\
\text { Tuntas }\end{array}$ \\
\hline
\end{tabular}

Berdasarkan Tabel di atas terlihat bahwa hasil belajar siswa sangat rendah. Nilai tertinggi yang diperoleh siswa adalah 70 dan nilai terendah adalah 20. Kelas tersebut belum mencapai ketuntasan belajar karena hanya ada 2 orang siswa yang dapat melampaui nilai KKM yakni 70,00, sedangkan yang belum tuntas belajar sebanyak 34 (94\%) siswa.

\section{Deskripsi Hasil Penelitian siklus I}

\section{a. Permasalahan}

Setelah pretes selesai diberikan dan nilai siswa sudah diperoleh, maka dapat terlihat bahwa hasil belajar siswa sangat rendah, dikatakan sangat rendah karena tidak ada siswa yang tuntas belajar Ini berarti semua siswa kelas X Otomatisasi dan Tata Kelola Perkantoran 2 di SMK Negeri 7 Medan belum memahami

Kompetensi

DasarMengoperasikan Program Microsoft Powerpointdalam pelajaran Teknologi perkantoran yang telah diberikan guru.

Berdasarkan data diatas maka ditemukan beberapa masalah yang akan dihadapi pada siklus I yang akan dilaksanakan, yaitu :

1.Siswa mengalami kesulitan dalam memahami materi pelajaran yang diberikan oleh guru karena guru terlalu cepat dalam menjelaskan materi pelajaran dan guru tidak menguasai kelas.

2.Siswa masih menemukan kesulitan dalam mengoprasikan komputer yang diberikan oleh guru karena siswa lebih banyak bermain daripada mendengarkan penjelasan dari guru.

3. Siswa belum terbiasa memahami materi dengan penggunaan media.

\section{b. Alternatif Pemecahan (Rencana Tindakan I)}

Berdasarkan permasalahan yang telah ditemukan pada pengamatan awal, maka peneliti membuat alternatif pemecahan masalah dengan melakukan serangkaian tindakan sebagai berikut :

1. Menjelaskan bagaimana mengoperasikan Program Microsoft Powerpoint

2. Menjelaskan dengan menggunakan perangkat komputer

3. Membagi siswa menjadi 4 kelompok belajar, setiap kelompok diberikan tugas untuk dibahas dalam dalam diskusi kelompok.

4. Memandu siswa untuk mengamati Mengoperasikan Program Microsoft Powerpointsesuai dengan masing-masing kelompok

5. Menyajikan permasalahan yang sama kepada setiap kelompok

6. Memantau siswa dalam mengerjakan tugas kelompok

7. Menyuruh siswa untuk mempresentasikan hasil diskusinya di depan kelas 
8. Membimbing siswa untuk memberikan saran dan kritik untuk kelompok penyaji

9. Membimbing siswa untuk memberikan umpan balik terhadap pertanyaan dari kelompok lain sehingga diskusi tidak pasif.

10. Pada akhir pertemuan siklus I guru memberikan postes kepada siswa secara individu.

\section{c. Pelaksanaan Tindakan}

Pada tahap pelaksanaan tindakan ini peneliti melaksanakan kegiatan belajar mengajar berdasarkan RPP yang telah disusun. Adapun kegiatan belajar mengajar yang dilakukan dimulai dengan :

1.Membuka pelajaran

2.Menjelaskan pengertian Program Microsoft Power Poin

3.Menjelaskan dengan menggunakan alat yang dipakai seperti komputer

4.Membagi siswa menjadi 4 kelompok belajar, setiap kelompok diberikan tugas untuk dibahas dalam dalam diskusi kelompok.

5.Memandu siswa untuk mencari hal-hal yang kurang dimengerti untuk disajikan dalam diskusi

6. Menyajikan permasalahan yang sama kepada setiap kelompok

7.Memantau siswa dalam mengerjakan tugas kelompok

8.Menyuruh siswa untuk mempresentasikan hasil diskusinya di depan kelas

9.Membimbing siswa untuk memberikan saran dan kritik untuk kelompok penyaji.

10. Membimbing siswa untuk memberikan umpan balik terhadap pertanyaan dari kelompok lain sehingga diskusi tidak pasif.

11. Siswa bersama-sama dengan guru menyimpulkan materi pelajaran

12. Di akhir siklus ini siswa diberikan postes secara individu yang bertujuan untuk melihat keberhasilan tindakan yang telah diberikan, kemampuan siswa dalam memahami materi pelajaran dan menyelesaikan tugas yang telah diberikan serta melihat kesulitan-kesulitan yang masih dialami siswa.

\section{d. Observasi dan Evaluasi I}

Observasi dilakukan untuk melihat sejauhmana proses pembelajaran berlangsung. Lembar observasi digunakan untuk mengamati guru dalam menerapkan model pembelajaran interaktif kepada siswa kelas X Otomatisasi dan Tata Kelola Perkantoran 2 SMK Negeri 7 Medan.

Berikut ini adalah lembar observasi pada siklus I

Tabel 3 Lembar Observasi Guru Siklus I

\begin{tabular}{|c|c|c|c|c|c|}
\hline No & Kegiatan & $\mathbf{1}$ & 2 & 3 & 4 \\
\hline 1 & $\begin{array}{l}\text { Urutan langkah-langkah kegiatan } \\
\text { pembelajaran }\end{array}$ & & & $\sqrt{ }$ & \\
\hline 2 & Menjelaskan materi & & & $\sqrt{ }$ & \\
\hline 3 & $\begin{array}{l}\text { Keaktifan guru dalam mengelola } \\
\text { kegiatan belajar mengajar di dalam } \\
\text { kelas }\end{array}$ & & $\sqrt{ }$ & & \\
\hline 4 & $\begin{array}{l}\text { Memberikan petunjuk kepada siswa } \\
\text { tentang tugas-tugas yang akan } \\
\text { dikerjakan oleh siswa }\end{array}$ & & $\sqrt{ }$ & & \\
\hline 5 & $\begin{array}{l}\text { Keaktifan guru membantu siswa } \\
\text { membagi dan mengelola kelompok }\end{array}$ & & $\sqrt{ }$ & & \\
\hline 6 & $\begin{array}{l}\text { Meminta siswa untuk saling bekerja } \\
\text { sama dalam mengerjakan tugas } \\
\text { kelompok }\end{array}$ & & $\sqrt{ }$ & & \\
\hline 7 & $\begin{array}{l}\text { Memberikan kesempatan kepada } \\
\text { siswa untuk bertanya }\end{array}$ & & $\sqrt{ }$ & & \\
\hline 8 & $\begin{array}{l}\text { Memberikan respon atas pertanyaan } \\
\text { siswa }\end{array}$ & & & $\sqrt{ }$ & \\
\hline 9 & Menyimpulkan hasil pembelajaran & & & & $\sqrt{ }$ \\
\hline 10 & Memberikan tes kepada siswa & & & & $\sqrt{ }$ \\
\hline
\end{tabular}

baik $\quad 4=$ sangat baik

$$
\begin{aligned}
\text { Nilai } & =\frac{27}{40} \times 4 \\
& =2,7
\end{aligned}
$$

Berdasarkan nilai observasi yang diperoleh, terlihat jelas bahwa guru belum dapat menerapkan model pembelajaran 
interaktif dengan baik selama proses belajar mengajar berlangsung. Guru belum dapat mengelola kegiatan belajar di kelas sehingga siswa siswa lebih banyak bermain daripada belajar. Selain itu guru juga kurang memberikan kesempatan bertanya kepada siswa sehingga siswa lebih banyak diam.

Berdasarkan tes yang dilakukan, hasil belajar siswa belum memuaskan, hal ini ditandai dengan penguasaan siswa masih di bawah standar nilai yang ditetapkan. Hasil belajar siswa pada tes siklus I dapat dilihat pada tabel di bawah ini :

Tabel 4. Data Hasil Belajar Siswa Pada Tes Siklus I

\begin{tabular}{|c|c|c|c|}
\hline No. & Nama & Nilai & Keterangan \\
\hline 1 & 01 & 35 & Belum Tuntas \\
\hline 2 & 02 & 70 & Tuntas \\
\hline 3 & 03 & 35 & Belum Tuntas \\
\hline 4 & 04 & 60 & Belum Tuntas \\
\hline 5 & 05 & 60 & Belum Tuntas \\
\hline 6 & 06 & 60 & Belum Tuntas \\
\hline 7 & 07 & 80 & Tuntas \\
\hline 8 & 08 & 50 & Belum Tuntas \\
\hline 9 & 09 & 70 & Tuntas \\
\hline 10 & 10 & 80 & Tuntas \\
\hline 11 & 11 & 30 & Belum Tuntas \\
\hline 12 & 12 & 20 & Belum Tuntas \\
\hline 13 & 13 & 70 & Tuntas \\
\hline 14 & 14 & 40 & Belum Tuntas \\
\hline 15 & 15 & 50 & Belum Tuntas \\
\hline 16 & 16 & 70 & Tuntas \\
\hline 17 & 17 & 50 & Belum Tuntas \\
\hline 18 & 18 & 30 & Belum Tuntas \\
\hline 19 & 19 & 50 & Belum Tuntas \\
\hline 20 & 20 & 35 & Belum Tuntas \\
\hline 21 & 21 & 35 & Belum Tuntas \\
\hline 22 & 22 & 70 & Tuntas \\
\hline 23 & 23 & 35 & Belum Tuntas \\
\hline 24 & 24 & 60 & Belum Tuntas \\
\hline 25 & 25 & 60 & Belum Tuntas \\
\hline 26 & 26 & 60 & Belum Tuntas \\
\hline 27 & 27 & 80 & Tuntas \\
\hline 28 & 28 & 50 & Belum Tuntas \\
\hline 29 & 29 & 70 & Tuntas \\
\hline 30 & 30 & 80 & Tuntas \\
\hline 31 & 31 & 30 & Belum Tuntas \\
\hline 32 & 31 & 20 & Belum Tuntas \\
\hline 33 & 33 & 70 & Tuntas \\
\hline 34 & 34 & 40 & Belum Tuntas \\
\hline 35 & 35 & 50 & Belum Tuntas \\
\hline 36 & 36 & 70 & Tuntas \\
\hline \multicolumn{2}{|c|}{ Jumlah Nilai } & 1872 & \\
\hline \multicolumn{2}{|c|}{ Rata-rata Nilai } & 52 & \\
\hline
\end{tabular}

Tabel 5 Data Hasil Tes Siklus I Siswa Kelas IXSMK Negeri 7Medan

\begin{tabular}{|c|c|c|c|c|}
\hline No & Nilai & Jumlah & Persentase & Keterangan \\
\hline 1 & $70-100$ & 12 & $33 \%$ & Tuntas \\
\hline 2 & $0-69$ & 24 & $67 \%$ & Tuntas \\
\hline
\end{tabular}

Mencermati Tabel 5 di atas, perolehan hasil belajar siswa masih rendah dan belum memenuhi kriteria ketuntasan yang telah ditetapkan, karena hanya 12 (33\%) siswa yang nilainya memenuhi standar ketuntasan belajar sedangkan $24(67 \%)$ siswa yang lainnya tidak memenuhi standar ketuntasan belajar. Ini berarti bahwa tujuan pembelajaran yang diharapkan belum tercapai. Meskipun ada peningkatan hasil belajar siswa pada siklus I dibandingkan dengan hasil belajar siswa pada pretes, namun hasil belajar siswa yang dicapai masih belum optimal, karena itu penelitian kembali dilanjutkan kepada siklus II.

\section{e. Refleksi I}

Pada siklus I pembelajaran, nampak perubahan pola belajar siswa akibat diterapkan pembelajaran dengan menggunakan model pembelajaran interaktif. Karena biasanya, guru hanya menggunakan metode konvensional yang mengakibatkan siswa pasif hanya menerima informasi saja. Tetapi penerapan pembelajaran dengan menggunakan model pembelajaran interaktif ini menjadikan siswa lebih aktif dan memberikan motivasi baru kepada siswa untuk menyelesaikan tugas yang telah diberikan kepada mereka dengan cara berdiskusi. Pembelajaran dengan menggunakan model pembelajaran interaktif memancing siswa untuk berani bertanya dan mengeluarkan pendapat kepada orang lain.

Walaupun sudah terlihat ada $33 \%$ siswa yang memenuhi standar ketuntasan belajar dan sudah terlihat perubahan terhadap suasana pembelajaran tetapi masih ditemukan masalah-masalah yang menyebabkan kurang optimalnya hasil belajar siswa yang dicapai, seperti siswa masih kurang aktif, motivasi belajar siswa masih rendah, siswa masih kurang berani bertanya, siswa masih belum bisa bekerjasama dengan kelompoknya dalam menyelesaikan tugas yang ada. Karena hasil 
belajar siswa yang masih rendah dan ditemukan beberapa permasalahan pada siklus I, maka penelitian perlu dilanjutkan ke siklus II.

\section{Deskripsi Hasil Penelitian Siklus II Permasalahan}

Permasalahan yang dihadapi pada siklus I adalah:

1. Hasil siswa yang masih rendah

2. Guru kurang memberikan kesempatan bertanya kepada siswa

3. Kurangnya keaktifan guru dalam mengelola kelas

4. Siswa terlalu banyak dalam satu kelompok

\section{Alternatif Pemecahan (Rencana Tindakan}

II)

Berdasarkan analisis dan refleksi pada siklus I, maka langkah yang perlu diperbaiki pada siklus II adalah :

1. Peneliti memperbaiki Rencana Pelaksanaan Pembelajaran (RPP) berdasarkan kesulitan-kesulitan yang telah ditemukan pada siklus I.

2. Peneliti menjelaskan kembali materi pelajaran dengan menggunakan kata kunci

3. Guru membagi siswa menjadi 8 kelompok dengan masing-masing kelompok terdiri dari5 orang.

4. Guru memberikan masalah yang akan didiskusikan oleh setiap kelompok

5. Selama pembelajaran berlangsung, peneliti dibantu oleh guru kelas melakukan observasi untuk melihat keaktifan guru dan efektifitas pelaksanaan pembelajaran yang dilakukan peneliti.

6. Guru mengawasi berjalannya diskusi kelompok

7. Guru memberikan kesempatan bertanya penuh kepada siswa

8. Setelah siswa selesai melakukan diskusi kelompok peneliti menyuruh perwakilan masing-masing kelompok untuk membacakan hasil diskusinya di depan kelas.

9. Setelah selesai maka hasil diskusi kelompok dikumpulkan untuk dinilai guru.
10.Pada akhir pertemuan siklus II guru memberikan postes pada siswa.

\section{a. Pelaksanaan Tindakan II}

1. Peneliti memperbaiki Rencana Pelaksanaan Pembelajaran (RPP) berdasarkan kesulitan-kesulitan yang telah ditemukan pada siklus I.

2. Peneliti menjelaskan materi pelajaran dengan menggunakan kata kunci

3. Guru membagi siswa menjadi 8 kelompok dengan masing-masing kelompok terdiri dari 5 orang.

4. Guru memberikan masalah yang akan didiskusikan oleh setiap kelompok

5. Selama pembelajaran berlangsung, peneliti dibantu oleh guru kelas melakukan observasi untuk melihat keaktifan guru dan efektifitas pelaksanaan pembelajaran yang dilakukan peneliti.

6. Guru mengawasi berjalannya diskusi kelompok

7. Guru memberikan kesempatan bertanya penuh kepada siswa

8. Setelah siswa selesai melakukan diskusi kelompok peneliti menyuruh perwakilan masing-masing kelompok untuk membacakan hasil diskusinya di depan kelas.

9. Setelah selesai maka hasil diskusi kelompok dikumpulkan untuk dinilai guru.

10. Pada akhir pertemuan siklus II guru memberikan postes pada siswa.

Pada siklus II pembelajaran lebih banyak ditekankan kepada siswa agar siswa dapat lebih aktif dalam mengikuti pembelajaran dan berani bertanya dan mengajukan pendapat kepada orang lain serta agar dapat meningkatkan hasil belajar siswa.

\section{b. Observasi dan Evaluasi II}

Berikut ini adalah lembar observasi pada siklus II 
Tabel 6 Lembar Observasi Guru Siklus II

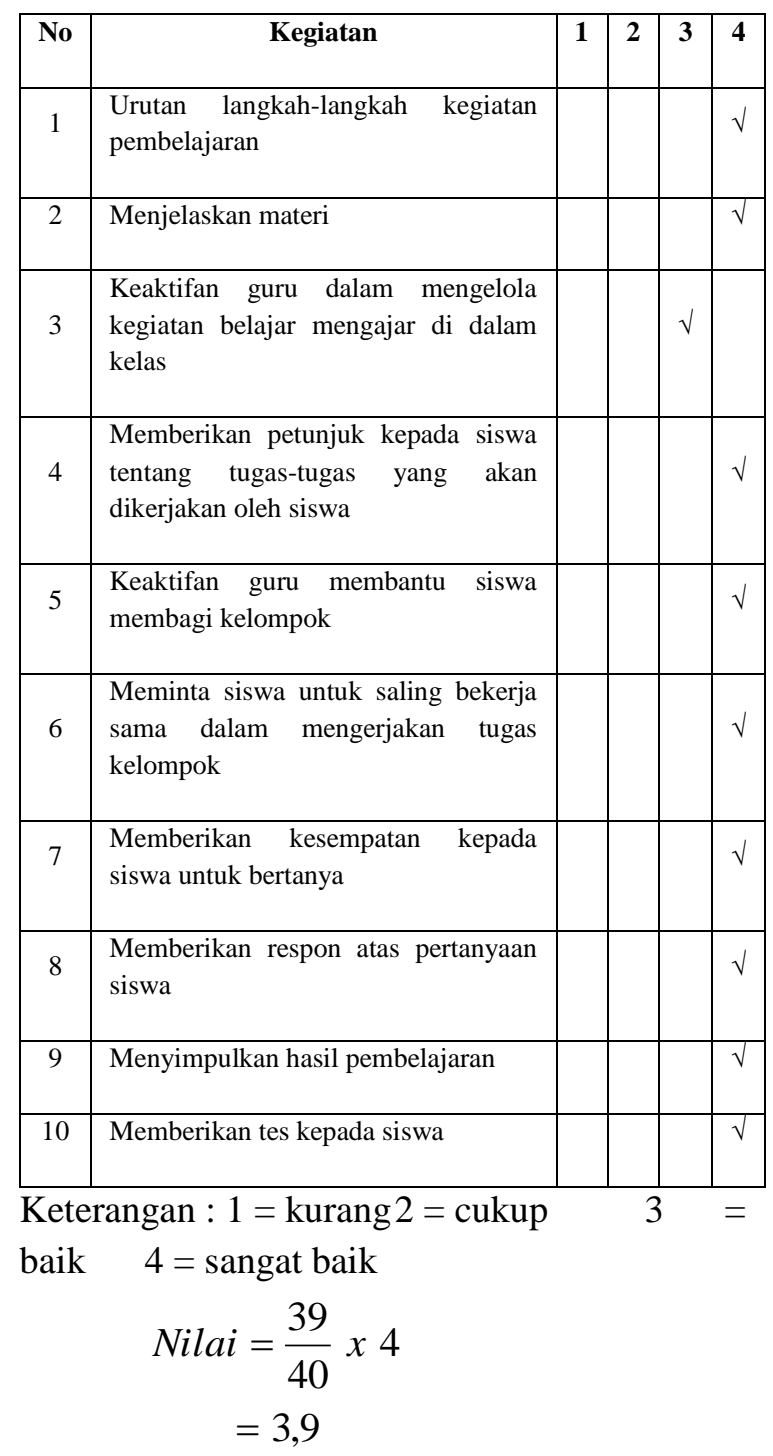

Berdasarkan hasil observasi yang dilakukan, terlihat guru telah berhasil menerapkan model pembelajaran interaktif terhadap siswa. Hal ini ditunjukkan pada tabel pengamatan untuk guru selama proses belajar mengajar. Pada siklus II yang masih melibatkan sebanyak 20 siswa terlihat bahwa guru telah berhasil menerapkan model pembelajaran interaktif. Secara umum siswa mulai serius dalam mengikuti proses belajar mengajar dan aktif bertanya dan mengungkapkan pendapat kepada orang lain, siswa juga telah aktif melakukan diskusi kelompok.

Apabila dilihat dari nilai yang diperoleh siswa, maka terjadi peningkatan.
Peningkatan nilai tersebut dapat dilihat pada tabel di bawah ini :

Tabel 7 Daftar Nilai Siswa Pada Tes Siklus II

\begin{tabular}{|c|c|c|c|}
\hline No. & Nama & Nilai & Keterangan \\
\hline 1 & 01 & 80 & Tuntas \\
\hline 2 & 02 & 70 & Tuntas \\
\hline 3 & 03 & 70 & Tuntas \\
\hline 4 & 04 & 70 & Tuntas \\
\hline 5 & 05 & 70 & Tuntas \\
\hline 6 & 06 & 60 & Belum Tuntas \\
\hline 7 & 07 & 70 & Tuntas \\
\hline 8 & 08 & 80 & Tuntas \\
\hline 9 & 09 & 70 & Tuntas \\
\hline 10 & 10 & 80 & Tuntas \\
\hline 11 & 11 & 70 & Tuntas \\
\hline 12 & 12 & 80 & Tuntas \\
\hline 13 & 13 & 90 & Tuntas \\
\hline 14 & 14 & 80 & Tuntas \\
\hline 15 & 15 & 80 & Tuntas \\
\hline 16 & 16 & 80 & Tuntas \\
\hline 17 & 17 & 90 & Tuntas \\
\hline 18 & 18 & 80 & Tuntas \\
\hline 19 & 19 & 80 & Tuntas \\
\hline 20 & 20 & 70 & Tuntas \\
\hline 21 & 21 & 80 & Tuntas \\
\hline 22 & 22 & 60 & Belum Tuntas \\
\hline 23 & 23 & 70 & Tuntas \\
\hline 24 & 24 & 70 & Tuntas \\
\hline 25 & 25 & 70 & Tuntas \\
\hline 26 & 26 & 70 & Tuntas \\
\hline 27 & 27 & 70 & Tuntas \\
\hline 28 & 28 & 80 & Tuntas \\
\hline 29 & 29 & 70 & Tuntas \\
\hline 30 & 30 & 80 & Tuntas \\
\hline 31 & 31 & 70 & Tuntas \\
\hline 32 & 32 & 80 & Tuntas \\
\hline 33 & 33 & 90 & Tuntas \\
\hline 34 & 34 & 80 & Tuntas \\
\hline 35 & 35 & 80 & Tuntas \\
\hline 36 & 36 & 80 & Tuntas \\
\hline \multicolumn{2}{|c|}{ Jumlah Nilai } & 2700 & \\
\hline \multicolumn{2}{|c|}{ Rata-rata Nilai } & 75 & \\
\hline
\end{tabular}

Tabel 8 Data Hasil Tes Siklus II Siswa Kelas X Otomatisasi dan Tata Kelola Perkantoran 2 SMK Negeri 7. Medan

\begin{tabular}{|c|c|c|c|c|}
\hline No & Nilai & Jumlah & Persentase & Keterangan \\
\hline 1 & $70-100$ & 34 & $94 \%$ & Tuntas \\
\hline 2 & $0-69$ & 2 & $6 \%$ & $\begin{array}{c}\text { Belum } \\
\text { Tuntas }\end{array}$ \\
\hline
\end{tabular}

Berdasarkan Tabel 8 di atas terlihat bahwa hasil belajar siswa telah meningkat. Dari 36 siswa sebanyak 34 (94\%) siswa telah memenuhi kriteria ketuntasan belajar yang 
telah ditetapkan dan hanya $2(6 \%)$ yang tidak memenuhi ketuntasan minimal. Oleh sebab itu peneliti tidak perlu merancang tindakan pada siklus selanjutnya.

Perbandingan hasil belajar siswa pada pretes, siklus I, dan siklus II dapat dilihat pada tabel berikut ini :

Tabel 9 Perbandingan Hasil Belajar Siswa pada Pretes, Siklus I, dan Siklus II

\begin{tabular}{|c|l|c|c|c|}
\hline No & \multicolumn{1}{|c|}{ Hasil Belajar } & Pretes & Siklus I & $\begin{array}{c}\text { Siklus } \\
\text { II }\end{array}$ \\
\hline 1 & $\begin{array}{l}\text { Siswa yang tuntas } \\
\text { belajar }\end{array}$ & 6 & 33 & 94 \\
\hline 2 & $\begin{array}{l}\text { Siswa yang belum tuntas } \\
\text { belajar }\end{array}$ & 94 & 67 & 6 \\
\hline
\end{tabular}

\section{c. Refleksi II}

Memasuki siklus II terjadi perubahan segala aktifitas belajar siswa. Siswa sudah berani bertanya apabila mereka belum mengerti dengan materi pelajaran. Selain itu siswa juga sudah dapat bekerjasama dengan teman sekelompoknya dalam menyelesaikan masalah yang ada. Dengan meningkatnya perubahan pada siswa maka meningkat juga hasil belajar yang diperoleh siswa. Dengan demikian, terbukti bahwa model pembelajaran interaktif yang diterapkan pada penelitian ini dapat meningkatkan hasil belajar siswa.

Dari pengamatan dan evaluasi yang dilakukan guru, terlihat bahwa terjadi peningkatan hasil belajar siswa. Sebanyak 34 (94\%) siswa yang telah memenuhi kriteria ketuntasan belajar yang ditetapkan dan tidak perlu mengikuti pembelajaran perbaikan sedangkan yang tidak memenuhi kriteria ketuntasan belajar hanya $2(6 \%)$ siswa. Dengan demikian, tindakan sudah selesai dan tidak perlu lagi dilanjutkan pada siklus III.

\section{Pembahasan}

Hasil belajar merupakan hasil yang terjadi setelah melakukan aktifitas belajar. Hasil belajar siswa dapat dilihat dari hasil belajar yang telah diperoleh siswa melalui tes yang diberikan guru setelah proses pembelajaran selesai. Tes ini dapat melihat sejauhmana kemampuan siswa memahami materi pelajaran yang diberikan oleh guru.
Selain itu, dengan adanya tes maka guru juga dapat mengetahui apakah pengajaran yang telah diberikan kepada anak didiknya berhasil atau tidak. Apabila 65\% siswa memperoleh nilai sesuai dengan ketentuan ketuntasan belajar maka guru tersebut dapat dikatakan berhasil dalam melakukan pengajaran. Namun pada kenyataanya hasil yang diperoleh siswa masih rendah.

Dan pada saat peneliti melihat dilapangan masih banyak ditemukan siswa yang pasif dan hanya menerima informasi dari guru saja, bahkan masih banyak siswa yang tidak berani bertanya kepada guru walaupun sebenarnya mereka belum mengerti dengan materi yang diajarkan guru. Semua ini disebabkan karena guru masih menerapkan pembelajaran konvensional yang umumnya menggunakan metode ceramah. Akibatnya, guru yang capek mengajar sedangkan siswa kurang antusias mendengarkan penjelasan yang diberikan guru, bahkan pembelajaran seperti ini hanya menghasilkan siswa yang pasif dan kurang kreatif. Padahal dalam setiap pembelajaran minat dan motivasi belajar siswa harus ditumbuhkan terlebih dahulu.

Dengan adanya minat belajar tentunya siswa akan termotivasi untuk belajar yang ditunjukkan dengan keseriusannya mendengarkan materi pelajaran yang dijelaskan oleh guru. Jika siswa serius belajar maka guru akan lebih mudah dalam memberikan materi pelajaran kepada siswa. Apabila siswa sudah serius untuk belajar maka hasil belajar siswa juga akan meningkat.

Guru harus menyadari bahwa ia adalah faktor eksternal yang sangat mempengaruhi hasil belajar siswa, karena itu ia harus tanggap terhadap tuntutan keterampilan mengajar yang semakin berkembang, termasuk dalam menerapkan model pembelajaran interaktif pada pokok bahasan listrik statis.

Pada kenyataannya, terbukti dengan menerapkan model pembelajaran interaktif pada Kompetensi DasarMengoperasikan Program Microsoft Powerpointdapat meningkatkan hasil belajar siswa walaupun 
pada siklus I belum memuaskan dengan hasil yang diperoleh karena hanya $2(6 \%)$ siswa yang nilainya memenuhi standar ketuntasan belajar sedangkan 34 (94\%) siswa yang lainnya tidak memenuhi standar ketuntasan belajar. Namun setelah dilakukan perbaikan pada siklus II ternyata terjadi peningkatan. Dari $12(33 \%)$ siswa yang tuntas belajar pada siklus I meningkat pada siklus II menjadi 34 (94\%) siswa yang tuntas belajar dan hanya 2 (6\%) siswa yang tidak tuntas belajar.

Penggunaan model pembelajaran interaktif dalam penelitian ini dapat meningkatkan hasil belajar siswa pada Kompetensi Dasar Mengoperasikan Program Microsoft Powerpointdalam mata pelajaran Teknologi Perkantoran. Selain itu, penggunaan model pembelajaran interaktif juga dapat merangsang siswa lebih aktif dalam mengikuti proses pembelajaran, siswa berani bertanya kepada guru, saat proses belajar mengajar sedang berlangsung dan siswa juga berani mengungkapkan pendapatnya kepada orang lain.

Penelitian terdahulu Dra. Suprayetkti, M.Pd, mengatakan bahwa Kinerja belajar siswa meningkat setelah pembelajaran IPA menggunakan model pembelajaran interaktif. Siswa sangat antusias membahas topik dalam diskusi, dan berusaha menjawab dan menemukan informasi tentang topik tersebut. bekerja sama, bersahabat tanpa memperhatikan kepintaran atau kemampuan orang lain. Justru siswa yang memiliki kelebihan daripada temantemannya dapat membantunya dengan memberikan penjelasan tentang teori/materi pelajaran yang belum dipahami dan dimengerti. Siswa saling berebut mengemukakan informasi (apa yang mereka ketahui) tentang topik. Setelah dilakukan pembagian tugas kelompok siswa bekerja sesuai dengan tugasnya masingmasing.

Ida Sriyanti Program Studi Pendidikan

Fisika Universitas Penerapan Model
Pembelajaran Interaktif Berbasis Konsep Sriwijaya, Palembang Berdasarkan hasil penelitiannya bahwa model pembelajaran interaktif berbasis konsep dapat diterapkan untuk meningkatkan aktivitas, pemahaman konsep dan hasil belajar Pendahuluan Fisika Zat Padat mahasiswa. Pada siklus II (terakhir) diperoleh persentasi keaktifanmahasiswa sebesar $85 \%$ (tergolong tinggi) dan ketuntasan belajar untuk seluruh mahasiswa $75 \%$. Dari hasil penelitian ini dapat disarankan bahwa model pembelajaran interaktif berbasis konsep layak dikembangkan sebagai alternatif model pembelajaran yang dapat digunakan dalam perkuliahan Pendahuluan Fisika Zat Padat dan pada materi pembelajaran Fisika di tingkat Sekolah Menegah Umum (SMU).

Dengan demikian berdasarkan hasil penelitian yang dilakukan di SMK Negeri 7Medan T.P2018/2019 bagi siswa kelas X Otomatisasi dan Tata Kelola Perkantoran 2 pada Kompetensi DasarMengoperasikan Program Microsoft Powerpoint dengan menggunakan model pembelajaran interaktif dapat disimpulkan bahwa penggunaan model pembelajaran interaktif tersebut dapat meningkatkan hasil belajar siswa pada pelajaran Teknologi Perkantoran .

\section{KESIMPULAN DAN SARAN}

Kesimpulan

Berdasarkan pembahasan hasil penelitian yang telah dilaksanakan, maka dapat diperoleh kesimpulan :

- Awalnya siswa mengalami kesulitan bekerja dalam kelompok, karena ada siswa yang merasa pintar dan ada juga yang minder karena kurang pandai, di sinilah peran Guru menjelaskan peran model pembelajaran interaktif sehingga siswa mau bekerja sama saling berbagi dan menghilangkan perbedaan.

- Dengan menggunakan model pembelajaran interaktif dapat 
meningkatkan hasil belajar siswa pada Mengoperasikan Program Microsoft Power Point di kelas X Otomatisasi dan Tata Kelola Perkantoran 2 SMK Negeri 7 Medan T.P2018/2019. Hal ini terbukti dari: terjadi peningkatan yaitu rata-rata nilai 75 dengan tingkat ketuntasan belajar $94 \%$ dan yang tidak tuntas belajar hanya $6 \%$ siswa.

\section{Saran}

Berdasarkan hasil penelitian dan kesimpulan-kesimpulan di atas, maka sebagai tindak lanjut penelitian ini disarankan beberapa hal sebagai berikut :

1. Diharapkan kepada guru kelas $X$ untuk dapat menggunakan model pembelajaran interaktif dalam proses pembelajaran khususnya pada mata pelajaran Teknologi Perkantoran Kompetensi DasarMengoperasikan Program Microsoft Powerpointatau pokok bahasan pada mata pelajaran lain, karena model pembelajaran interaktif dapat meningkatkan aktivitas siswa dan hasil belajar siswa. Bagi siswa sendiri diharapkan agar dapat mengikuti proses belajar mengajar dengan penggunaan model pembelajaran interaktif pada Kompetensi DasarMengoperasikan Program Microsoft Powerpoint

\section{REFERENSI}

Aqib, Diniati, Khotimah. 2010. Penelitian Tindakan Kelas. Bandung: Yrama Widya.

Arikunto, Suharsimi. 2006. Penelitian Tindakan Kelas. Jakarta: Bumi Aksara.

Djamarah, Zain. 2006. Strategi Belajar Mengajar. Jakarta: Rineka Cipta.

Hamalik, Oemar. 2010. Proses Belajar Mengajar. Jakarta: Bumi Aksara.

Rusman. 2010. Model-Model Pembelajaran Mengembangkan Profesionalisme Guru. Bandung: Rajawali Pers.

Sagala, Saiful. 2005. Konsep dan Makna Pembelajaran. Bandung: Alfabeta.
Sardiman. 2009. Interaksi dan Motivasi Belajar Mengajar. Jakarta: Raja Grafindo.

Slameto. 2003. Belajar dan Faktor-Faktor yang Mempengaruhinya. Jakarta: Rineka Cipta.

Sudjana, Nana. 2009. Penilaian Hasil Proses Belajar Mengajar. Bandung: Remaja Rosdakarya.

Suyatno. 2009. Menjelajah Pembelajaran Inovatif. Sidoarjo: Masmedia Buana Pustaka.

Syafaruddin, Nasution. 2005. Manajemen Pembelajaran. Jakarta: Quantum Teaching.

Syah, Muhibbin, 2010. Psikologi Pendidikan dengan Pendekatan Baru.Bandung: Remaja Rosdakarya.

Dra. Suprayetkti, M.Pd, 2008. Penerapan Model Pembelajaran Interaktif Pada Mata Pelajaran IPA Di SD Program Studi Teknologi Pendidikan, Fakultas Ilmu Pendidikan, Universitas Negeri Jakarta, Jurnal Teknodik Vol. XII No. 1 Juni 2008

Ida Sriyanti ,2009. Penerapan Model Pembelajaran Interaktif Berbasis Konsep. Palembang: Program Studi Pendidikan Fisika Universitas Sriwijaya. Ringin Gung Murti Sutomo, 2015. Peningkatan Hasil Belajar Siswa Mengggunakan Media Pembelajaran Interaktif. Bandung: UNNES

Sukamto, 2016. Penggunaan Model Pembelajaran Interaktif untuk Meningkatkan Prestasi Belajar...Jurnal Pendidikan Guru Sekolah Dasar . Bengkulu 